\title{
Sunk Costs, Innovation, and Spillover Effects in R\&D-intensive Industries
}

Dr. Anastassios Gentzoglanis, d'économque, Université de Sherbrooke, Canada

\begin{abstract}
This paper establishes a theoretical relationship between the sunkness of a firm's cost and its degree of innovation, as measured by the number of patents and trademarks introduced in the market. Departing from the assumption that incumbents and potential entrants are risk-averse, we demonstrate that the presence of sunk costs is not a barrier to entry, as it is usually considered to be, but it acts as a stimulus to R\&D activities. The empirical results confirm this assertion for the sample and the period examined. In the light of these results public policies encouraging $R \& D$ activities such as tax credits, grants, etc, should be reexamined carefully.
\end{abstract}

\section{Introduction}

The importance of technical change as a driving force of many economic activities and its impact on productivity and economic growth has long been recognized by many economists (Solow, 1957, Denison, 1967). The numerous theoretical and empirical studies realized in the past two decades or so (summarized in Kamien \& Schwartz, 1982) shed little light on the causes and the process of innovation. The old question whether more innovation results from competitive rather than monopolistic industrial structures is still debated, while the issue whether government $R \& D$ is considered to be a substitute to the private business $R \& D$ (crowding-out effect) has not been resolved as yet. The new literature on inter- and intra- industry $R \& D$ spillover effects ${ }^{1}$ (Jaffe, 1986, Bersnstein, 1988, Bernstein and Nadiri, 1988, etc.,) adds a new dimension to the old problem and tries to provide a more comprehensive explanation of the process of $R \& D$ activities across firms and industries.

Understanding the process of $R \& D$ is crucial especially in the present context of globalization and industrial restructuring. For one, the private sector could direct its $R \& D$ efforts and design competitive strategies more appropriately, while on the other hand, governments would implement appropriate science and technology policies that would foster an adequate $R \& D$ level for the country. Acquiring an adequate level (a minimum one) of $R \& D$ is important given that such a level would permit firms and countries to keep up or even to go ahead of competitors in productivity-enhancing technologies and provide the possibility to develop market niches in the sectors where domestic firms have an advantage.

This paper examines the nature and the process of innovation in the context of dynamic, Schumpeterian type of competition. It deals with the problems of innovation when industry structure is not given exogenously but is determined endogenously by firms' innovative activities. It recognizes that the process of innovation is not only a function of expected profits but also a function of the threat of actual or potential competition. It demonstrates that in markets where sunk costs (i.e., irrecoverable investments) are present incumbents as well as potential entrants tend to be process and/or product innovative. By contrast, in industries with low sunk costs barriers to entry as well as the risk of imitative entry are low. Potential entrants would then employ the imitative strategy while incumbents would prefer not to innovate for fear being easily imitated.

The next section briefly reviews the industrial organization and strategic management literature on the subject and it lays down the necessary elements to support our argument. In section III the relationship between sunk costs, the risk of entry and the innovative activity is established, while section IV discusses the rudiments of the data, the functional form specification, the estimation procedure and the results of the econometric regression used to determine the innovative performance of Canada's R\&D-intensive industrial sectors for the period 1987-1989. Lastly, section V draws policy implications on the outcome of the study and outlines general considerations for and against 
government R\&D policy instruments (tax credits, grants, etc) used to foster sciences and technology of the country.

\section{Innovation as a Dynamic Process: A Review of the Literature}

Economists have traditionally approached the complexities of the process of technological innovation by focusing on the market structure-technological innovation relation. The theoretical question whether monopolies, oligopolies or competitive markets are more conducive to innovation has been thoroughly examined (Kamien \& Schwartz, 1982). As yet, no firm conclusion has been derived from this analysis (Scherer and Ross, 1990). Then, the question has been attempted to be answered empirically. At the empirical level, the relation between industry's concentration ratio, firm size and the rate of technical change, as measured by patents, R\&D expenditures and major innovations, has been tested as well. The results are ambivalent (Kamien and Schwartz, 1982) ${ }^{2}$.

More recent theories of market structure and innovation (Gilbert and Newbery, 1982, Harris and Vickers, 1987) focus on the relationship that may exist between profits, costs, the "intensity of rivarly" and the speed with which a new product or process innovation is introduced in the market. These theories try to understand and identify in more detail the underlying forces of change in the race for innovations. They recognize explicitly that change is coming from the innovative activity of the incumbents and from competitive pressures of actual or potential entrants.

Obviously incumbents are interested in innovative activity for securing their present as well as their future profits. The profit incentive, which has been recently termed the stand-alone incentive by Grossman and Shapiro (1987), is widely accepted as the driving force of innovative activity. Arrow (1962) demonstrated that a competitive market structure is more conducive to innovation than a monopolistic one because of the existence of a higher profit incentive in the former. Similarly, Reinganum (1985) in her dynamic generalization of Arrow's result demonstrated that the process of dynamic competition is characterized by Schumpeterian "creative destruction".

It has been demonstrated (Gilbert and Newbery, 1982, and Harris and Vickers, 1987) that innovative activity is undertaken in markets where the competitive threat is present. The competitive pressures of actual or potential entrants determine the rapidity with which an innovation is introduced. Gilbert and Newberry (1982) further suggest that incumbents will be engaged in preemptive patenting to inhibit the entry of new firms. Teece $(1981,1986)$ and von Hippel, (1982), on the other hand, argue that the holder of a specific asset (which gives rise to a sunk cost) is forced to enter the innovation race should he increase the probabilities to remain in the industry. A leapfrog-type of competition would result from this kind of rivalry between incumbents and potential entrants.

Recognizing that there may be considerable advantages from being first or second in the innovation race, the recent theories of innovation advance the argument that the intensity of rivalry is related to market structure and the number of rivals, i.e., the actual mumber of rivals and potential innovators. This is in spirit of Schumpeter's (1950, p. 85) analysis. To quote:

"It is hardly necessary to point out that competition (by innovation) acts not only when is being but also when it is merely an ever-present threat. It disciplines before it attacks. The businessman feels himself to be in a competitive situation even if he is alone in his field....In many cases, though not in all, this will in the long run enforce behavior very similar to the perfectly competitive pattern" (emphasis added).

When emphasis is given on the existing relationship between innovative activity and the competitive pressures (which come from actual or potential entrants), the new theories of market structure and innovation come to the conclusion that only incumbents win the innovation race. This conclusion reverses the ones reached by the older theories. It should be admitted that the new theories mark a great departure from the old ones and are moving to the right direction since they take into account the intensity of rivalry inside and outside the industry as a determinant factor of innovative activity. Notwithstanding their contribution, they neglect to take explicitly into account the firm's nature of costs (sunkness) as well as the profit incentive source of $R \& D$ in explaining the process of innovation.

Recently, Beath et al (1989) used a simple model of strategic R\&D competition and succeeded to demonstrate that both the profit incentive and the competitive threat incentive are the driving forces of R\&D undertaken by individual firms. Despite their interesting results, they leave unanswered the question whether the entrant or the incumbent is more likely to innovate successfully. As it is with the whole literature on the subject, they do not take into account the firm's nature of costs in explaining the dynamic nature and the process of innovation.

In this paper we are interested in examining the sources as well as the process of innovation and the relationship that may exist between innovation and the firm's cost structure. It is shown that sunk costs play a 
determinant role in the process of innovation by means of their effect on barriers to and the risk of entry. It is argued that heavy sunk costs may deter entry by imitation, but they cannot deter entry by innovation (Gentzoglanis, 1990). Incumbents as well as potential entrants must be innovative in order to survive. Competition by innovation becomes the disciplinary force of the market. The threat of it or its actual presence plays a determinant role in forcing incumbents to act efficiently. The next section elaborates the process of innovation and its relationship to sunk costs.

\section{Risk, Sunk Costs, and the Process of Innovation}

One of the objectives of this research is to demonstrate that when a firm's cost structure has sunk costs components, competition is manifested by investments in process and/or product innovations. Before an innovation takes place the firm must invest in capital whose share of irrecoverable costs (R\&D capital and physical capital) constitutes normally a major part of the whole investment. These irrecoverable costs (sunk costs) provide protection to incumbents against imitative entry given that the latter is a high risk activity. However, the existence of sunk costs does not provide protection from innovative entry, unless incumbents are engaged in a continuous pioneering $R \& D$, involving new products and production techniques, increasing thereby the possibilities of being a "big winner". It is thus suggestive to investigate the important role played by sunk costs in the innovation race.

To begin with we need to make an analytical distinction between imitative and innovative entry. For our purposes, imitative entry is defined as the replication of the incumbents' goods by an entrant who uses the incumbents' technology. On the contrary, innovative entry involves the introduction of either a new production technique or a product or both ${ }^{3}$. We shall show that in the presence of sunk costs innovative entry is more profitable than imitative entry. Yet, incumbents best response strategy is to introduce innovations ${ }^{4}$.

The nature and sources of sunk costs were carefully examined by the contestability theory economists. They suggested (Baumol et al, 1982, Dixit, 1980, Eaton and Lipsey, 1980, Spence, 1977, Friedman, 1979) that the capital's durability and the equipment's specialization (irrevocability) are the two main sources of sunkness of costs and therefore of barriers to entry. Kessides (1991) argues that sunk costs create an "asymmetry in the incremental cost and risk faced by an entrant and an incumbent.... The entrant's incremental cost includes the full amount of the sunk cost which are largerly bygone to the incumbent. In addition, the entrant's perceived risk of failure is apt to be larger than the risk already accepted by the incumbent".
The dedication of a firm's resources to a particular form locks the firm to certain activities until it has recovered the value of its specific capital. Assets' specificity and durability increases risk and the latter may affect the firm's decision to innovate. Risk seems to be the most important factor affecting a firm's decision to enter a market. If there are no sunk costs there are no costs to a firm exiting the market and consequently there is no risk of entry (economic loss). Inversely, the higher the sunk costs the higher would be the economic losses of exiting and therefore the higher the risk of entry. Consequently, the risk of entry should be an increasing function of sunk costs and the latter determines the long run competitive strategies available to incumbents and potential entrants. Given heavy sunk costs, new entrants have no choice but to enter by innovation. Imitative entry is not an optimal strategy given that the risk is high for a newcomer to sink capital in a product that already exists and is fully exploited by well entrenched incumbents. Incumbents on the other hand have no choice but to innovate. It is the ever-present threat of innovative entry that induces incumbents to be innovative. Sunk costs are thus the factor determining the allocation of resources between imitation and innovation through the riskness of the transaction. Indeed, sunk costs determine the risk of entry and the latter determines the choice between imitation and innovation.

It may be possible that sunk costs play the role of a tariff. To circumvent (by-pass) the barriers created by the presence of sunk costs firms work around diging out new products and techniques which would allow them to enter with lower costs or with entirely new products. Sunk costs provide an incentive to innovate. Yip (1982) referring to $R \& D$ (sunk costs) intensity as a potential barrier to entry argues that the same factors that give rise to entry barriers may be exploited by an entrant giving him an advantage over the incumbent which allows him to circumvent this entry barrier.

In R\&D-intensive industries we generally observe a high rate of process and/or product innovations. Because of the high-sunk-cost-character of these industries imitative entry is more difficult and/or more risky and therefore potential entrants seek alternative routes to entry. This could involve new products or cost-reducing process innovations. The latter must be radical, however, and not incremental ones. The incremental innovations work to the advantage of established firms (Burns and Stalker, 1986, Dewar and Dutton, 1986) while radical ones can be viewed as a "gateway to entry" (Abernathy and Clark, 1985, Roberts, 1980). According to Scherer and Ross (1990) the empirical evidence supports the view that actual and potential new entrants are the direct sources of innovation and they act as spurs to incumbents. 
FIGURE 1

FIRM'S COST STRUCTURE CHARACTERISTICS and R\&D DECISIONS

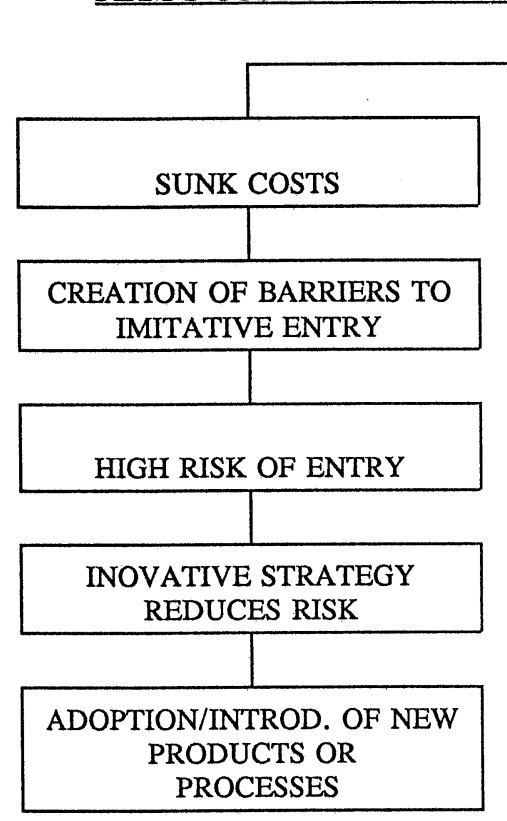

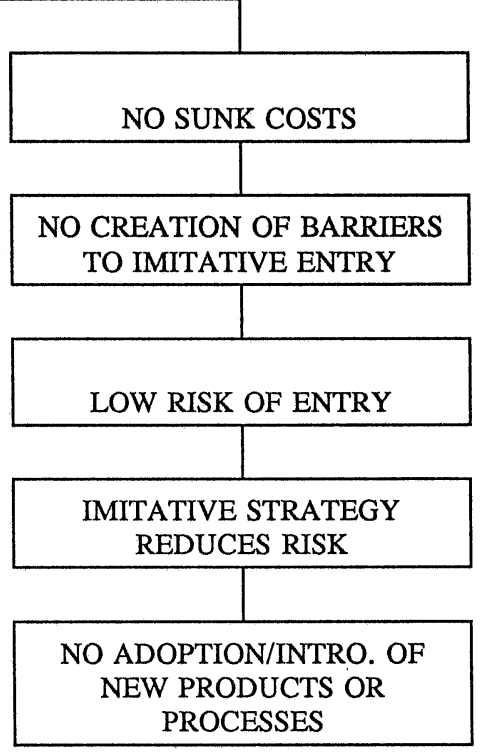

innovative entry. This is well resumed by Utterback (1979, p. 319) when he argues that:

"An important incentive for firms to attempt a risky technological innovation is their desire to survive in the face of effective competition, or rivalry, from other firms. Such rivalry can be especially effective if the competitor is a new entrant who has a new technological product or process that is superior to that of the existing firms in the industry.... Use of the new technology often has a much greater potential for improvement and cost reduction than does the existing technology. Thus price cutting by established firms as defence may be ineffective".
It is in the absence of sunk costs that imitative entry is most effective. Incumbents are discouraged since their innovations could be easily replicated by new entrants. By contrast, in the presence of sunk costs innovative entry is the most attractive strategy for potential entrants ${ }^{5}$. Figure 1 gives a schematic view of the relation between the firm's sunk cost function and innovative activity.

Given the ever-present threat of innovative entry incumbents become innovative as well. Schumpeter $(1950$, p. 102) reached this conclusion more than three decades ago. He stated:

"New methods of production or new commodities, especially the latter do not per se confer monopoly, even if used or produced by a single firm. The product of a new method has to compete with the products of the old ones and the new commodity has to be introduced, i.e., its demand schedule has to be built up. As a rule neither patents nor monopolistic practices avail against that....."

It is the threat (actual or potential) of technological competition that disciplines incumbents even if there is a single firm in the market. If the entry strategy is by means of new lower-cost technologies ${ }^{6}$, incumbents would be unable to sustain their competitive cost advantage in the long run unless they are involved in intensive R\&D activities as well ${ }^{7}$. Sunk costs act as a barrier to imitative entry but not as a barrier to

\section{Methodological Considerations and Empirical Evaluation}

\section{The Model}

It has been pointed out above that when the cost function has a high component of irrecoverable investments (SUNK), incumbents and entrants adopt the innovative strategy. Sunk costs are not, however, the only factor determining the innovative activity. When firms are choosing to invest in R\&D activities or to enter by innovation, they first decide upon the amount of R\&D capital ${ }^{8}$ and form some expectations concerning how the output rivalry with other firms will be resolved (depending on the industry's concentration ratio and history). Assuming that sunk costs are high at time zero (the time the investment in R\&D is decided) the magnitude of capitalization chosen by an entrant will depend on the properties of its variable cost function and the proportion of sunkness of costs to the total capital outlays. Given that expected profits $(\pi)$ are positive investments in $R \& D$ would occur.

We can assimilate the result of this strategy to the firm's innovation rate (INOV). This variable is obtained by dividing the total number of a firm's patents and trademarks (FPT\&TRM) by the total of the industry's (IPT\&TRM). The higher this ratio (INOV) the higher the firm's innovation rate. The empirical entry literature has employed variables such as concentration ratio, size 
and diversification, advertisement, profit expectations, the industry's growth rate and the degree of appropriability as explanatory variables of innovative performance. The equation to be estimated can be thus formulated in the following way:

$$
\mathrm{INOV}_{\mathrm{ij}}=\mathrm{f}\left(\mathrm{SUNK}_{\mathrm{i}}, \pi_{\mathrm{j}}, \mathrm{GR}_{\mathrm{j}}, \mathrm{APPR}, \mathrm{HH}\right)
$$

where

$$
\begin{aligned}
& \text { INOV }=\text { stands for the innovation rate } \\
& \text { i }=\text { stands for the firm } \\
& \mathrm{j}=\text { stands for the industry } \\
& \pi \quad=\text { expected profits } \\
& \text { SUNK }=\text { the sunk character of the firm's cost } \\
& \text { function } \\
& \mathrm{GR}=\text { the industry's growth rate } \\
& \text { APPR }=\text { an index of appropriability } \\
& \mathrm{HH}=\text { Hirschman-Herfindahl concentration index. }
\end{aligned}
$$

It is reasonable to argue that the longer a firm is in the market the lower will be its degree of sunkness of costs due to amortization. However, a depreciation rate applied to $R \& D$ capital should take into account not only its physical deterioration but also (and chiefly) the decline in the value of knowledge to an individual firm because of the introduction of new and better products and techniques in the market. The complexities in evaluating a firm's R\&D capital are described in the Appendix.

As far as the industry sales growth variable (GR) is concerned it seems reasonable to assume that the probabilities to invest in $R \& D$ activities are higher the higher the industry's growth rate. Undoubedtly, the degree of industry competition is high even in growth industries but this competition is less direct than in industries with low growth opportunities. In growth industries, the demand is increasing and, more often than not, is also more volatile than the demand in non-growth industries. Since growth opportunities enlarge the size of the market and create new ones, accomodation is becoming easier in this type of industries. In a way growth "softens" competition. Consequently, in growth industries, new entrants would anticipate a milder reaction from incumbents?

The possibility that a firm appropriates the benefits (APPR) of its own R\&D is an important factor determining its decision to invest in R\&D. When the technological pool is quite high and the inter-industry and intra-industry spillover effects strong (positive), investments in $R \& D$ and entry would occur. On the contrary, negative spillovers would dissuate entry and $\mathrm{R} \& \mathrm{D}$ investments ${ }^{10}$.

The Hirschman-Herfindahl (HH) index is included to capture the market structure character and the degree of competition prevailing in each industry. Yet, expected profits $(\pi)$ have been used in the literature as an explanatory variable of innovative performance. Expected profits cannot be calculated ex ante, however. For this reason the industry average past profit is usually used as a proxy of expected profit, on the assumption that the average past profitability will be repeated in the future.

\section{Data and Variables}

The sample is composed of 14 Canadian firms belonging to 9 major industrial sectors according to the Stock Guide TSE 300 classification. The criterion for a firm to be included in the sample was that it should have realized $R \& D$ and have obtained patents during the sample period covered by our study (1987-1989). Table 1 shows the effect of industrial structure on R\&D in 1987 for Canada. The high- and medium- intensity industry groups devoted together, on average, more than $\$ 2$ billion on R\&D or $17.8 \%$ of their sales, in 1987. The ratio drops sharply to only $0.6 \%$ in the traditional manufacturing and resource sectors. Put another way, the high intensity group of industries including in the sample accounted for almost $50 \%$ of total R\&D spending in 1987, while the low intensity group of industries accounted for only $22 \%$ of total R\&D spending. Canada's low ratios of R\&D spending to output is due to its industrial structure and to the low propensity of many Canadian firms to conduct R\&D, compared to other industrialized countries.

The annual data relating to investments in $R \& D$, industry's profits and sales are obtained from the Toronto Stock Guide TSE 300. The number of patents of the Canadian firms is obtained from PATDAT. The Hirschman-Herfindahl (HH) index is proxied by dividing each firm's annual sales by the sales of the industry.

The intra-mural spillover effects are obtained by subtracting the firm's R\&D from the sum of the industry's total R\&D. As far as the inter-industry spillover effects are concerned are obtained by subtracting the industry's total amount of R\&D from the sum of all sectors' R\&D. The sunk cost is obtained by applying a uniform rate of depreciation of $10 \%$ to each firm's total investment in R\&D considering that only a part of the total investment in R\&D is sunk ${ }^{11}$. It should be noted that the way we calculated the sunk variable here represents the recoverable part of the $R \& D$ investment.

\section{Empirical Estimations}

Equation (1) was estimated by pooling the time series and cross section data using the Generalized Least Squares technique (GLS). The estimated model takes on the following structure: 
TABLE 1

\begin{tabular}{|c|c|c|c|c|}
\hline \multicolumn{5}{|c|}{ Effect of Industrial Structure (1987 Data) on R\&D } \\
\hline Industry Group & R\&D & enses & $\begin{array}{c}\text { Sales } \\
\text { of Firms }\end{array}$ & $\begin{array}{l}\text { Group Sales } \\
\text { as \% of Total }\end{array}$ \\
\hline Industry Group & $\begin{array}{l}\text { as \% of } \\
\text { Sales }\end{array}$ & \$ Million & \$ Billion & $\%$ \\
\hline $\begin{array}{l}\text { High Intensity R\&D Industry Group } \\
\text { Aircraft and Parts } \\
\text { Telecommunications Equipment } \\
\text { Other Electronic Equipment } \\
\text { Engineering and Scientific Services } \\
\text { Computer Services }\end{array}$ & $\begin{array}{l}17.1 \\
16.9 \\
12.0 \\
11.9 \\
11.7 \\
14.4\end{array}$ & $\begin{array}{r}432 \\
549 \\
254 \\
294 \\
\underline{175} \\
1,704\end{array}$ & $\begin{array}{r}2.5 \\
3.2 \\
2.1 \\
2.5 \\
\underline{1.5} \\
11.8\end{array}$ & 4.5 \\
\hline $\begin{array}{l}\text { Medium Intensity R\&D Industry Group } \\
\text { Electronic Parts and Components } \\
\text { Business Machines } \\
\text { Drugs and Medicines } \\
\text { Machinery } \\
\text { Scientific and Professional Equipment } \\
\text { Other Manufacturing Industries }\end{array}$ & $\begin{array}{l}5.9 \\
3.7 \\
3.5 \\
3.2 \\
2.5 \\
2.3 \\
\\
3.4\end{array}$ & $\begin{array}{r}24 \\
216 \\
95 \\
72 \\
36 \\
29 \\
472\end{array}$ & $\begin{array}{r}0.4 \\
5.8 \\
2.7 \\
2.3 \\
1.4 \\
\underline{1.3} \\
13.9\end{array}$ & 5.3 \\
\hline $\begin{array}{l}\text { Low Intensity R\&D Industry Group } \\
\text { "High End" } \\
\text { Other Electrical Products } \\
\text { Primary Metals, non-ferrous } \\
\text { Other Chemical Products } \\
\text { Textiles } \\
\text { Metal Fabricating } \\
\text { Electrical Power }\end{array}$ & $\begin{array}{l}1.5 \\
1.3 \\
1.2 \\
1.1 \\
1.1 \\
1.0 \\
1.2\end{array}$ & $\begin{array}{r}58 \\
96 \\
151 \\
36 \\
29 \\
170 \\
540\end{array}$ & $\begin{array}{r}3.9 \\
7.4 \\
12.6 \\
3.3 \\
2.6 \\
17.0 \\
46.8\end{array}$ & 17.9 \\
\hline $\begin{array}{l}\text { "Low End" } \\
\text { Other Non-Manufacturing Industries } \\
\text { Rubber and Plastics Products } \\
\text { Mining } \\
\text { Wood } \\
\text { Crude Petroleum and Natural Gas } \\
\text { Refined Petroleum and Coal Products } \\
\text { Transportation and Other Utilities } \\
\text { Non-Metallic Mineral Products } \\
\text { Pulp and Paper } \\
\text { Primary Metals, ferrous } \\
\text { Other Transportation Equipment } \\
\text { Food, Beverages and Tobacco } \\
\end{array}$ & $\begin{array}{l}0.9 \\
0.7 \\
0.6 \\
0.6 \\
0.5 \\
0.5 \\
0.4 \\
0.4 \\
0.3 \\
0.3 \\
0.3 \\
0.2 \\
\\
0.4 \\
1.3\end{array}$ & $\begin{array}{r}189 \\
16 \\
43 \\
22 \\
26 \\
105 \\
111 \\
13 \\
69 \\
26 \\
93 \\
70 \\
783 \\
\\
3,501\end{array}$ & $\begin{array}{r}21.0 \\
2.3 \\
7.2 \\
3.7 \\
5.2 \\
21.0 \\
27.8 \\
3.3 \\
23.0 \\
8.7 \\
31.0 \\
35.0 \\
189.2 \\
\\
261.7\end{array}$ & $\begin{array}{l}71.3 \\
100.00\end{array}$ \\
\hline Source: Statistics Canada \#88-202 & & & & \\
\hline
\end{tabular}




$$
\begin{aligned}
\text { INOV }= & \beta_{1} \text { SUNK }+\beta_{2} \pi+\beta_{3} \text { GR }+\beta_{4} \text { INTRA + } \\
& \beta_{5} \text { INTER }+\beta_{6} \mathrm{HH}+\epsilon
\end{aligned}
$$

$\beta_{1}, \beta_{2}, \beta_{3}, \beta_{4}, \beta_{5}$ and $\beta_{6}$ are the parameters to estimate and $\epsilon$ is an error term. The error term is assumed to have constant variance (homoscedasticity) within each cross-section over time but is assumed to be heteroscedastic across each of the cross-sections ${ }^{12}$.

The results of the estimations, the associated tstatistics and the key overall statistics are set out in table 2 (see Apendix). These results are encouraging. The SUNK coefficient is significantly different from zero based on a t-test and 5\% confidence level but it is rather low indicating that an increase in the recoverable rate of R\&D investments induces firms to imitate rather than to innovate. This statement is in accordance with our assertion that low sunk costs imply low risk and therefore more competition by imitation.

The profit variable coefficient is statistically different from zero at the $10 \%$ confidence level and takes on the expected sign. The higher the industry's profit rate the higher the R\&D investments and presumably the patent rate.

The intra-spillovers coefficient is not significantly different from zero based on a t-test and $5 \%$ confidence level while the inter-industry spillovers coefficient is significantly different from zero based on the same test.

The HH coefficient is significantly different from zero based on a t-test and 5\% confidence level. It has a positive sign, implying that the overall level of competition in the industry plays a major role in determining the $R \& D$ race and eventually the outcome of it, i.e., the patent rate.

The growth coefficient is statistically different from zero and has a negative sign, implying that the higher the industry's growth rate the lower its patent rate, ceteris paribus. This result confirms our intuition according to which high industry growth rates softness competition reducing thereby the firm's patent rate performance.

From a policy pespective, the most important results from the regression analysis are that sunk costs act indeed as an incentive to innovation. Baumol's et al (1982) theoretical supposition that sunk costs are barriers to innovation is not empirically supported by this sample. While this study supports our own supposition, it should be noted, however, that important variables such as the firm's backward or forward integration (which may give rise to the control of the inputs used in the $R \& D$ process), or the extent to which the established firms control the distribution networks or the existence of agreements for R\&D cooperation, etc., were excluded from the model. These omitted variables may significantly affect the decision of a firm to enter by innovation or imitation irrespective of the presence or absence of sunk costs.

Nevertheless, the desirability of government R\&D policies (subsidies or tax credits) should be examined in a broader perspective. Given that government R\&D policies tend to reduce the cost of $R \& D$ we may observe more imitative technological competition rather than purely innovative competition. On these grounds some may doubt the efficiency of these programs in promoting genuine innovations in a country. However, such a policy should not be considered as ineffective. Many true innovations come from imitators who, after many years of imitation, discover entirely new products and techniques (example, Japanese firms). Such policies may be considered as a first step towards the creation of a country's technological pool essential for fostering a truly innovative competition. For a nation, like Canada, with a lack of tradition to the R\&D the use of various governmental instruments such as tax credits, grants, government laboratories, procurement policies, etc., in fostering R\&D may be essential.

\section{Summary and Conclusions}

In this study we developed and presented a theoretical model which linked the presence of sunk costs to innovative activity. The main result of the study is that the sunk character of a firm's costs does not act as a barrier to innovation but, on the contrary, it may be viewed as an incentive to innovation.

To verify this assertion, data were collected for 9 sectors and 14 firms which were involved in R\&D activites and have filed patents for the period over 1987-1989. The empirical results seem to confirm our hypothesis according to which sunk costs provide an incentive to innovation. Nevertheless, this finding should not be interpreted as evidence of inefficiencies of the government policies aiming at promoting firms' $\mathrm{R} \& \mathrm{D}$ activities. It is true that grants, subsidies or tax credits reduce the sunk character of firms' R\&D investments and that they divert a firm's R\&D activities from purely innovative to imitative ones. However, imitative entry is the first element of competition as we are currently observing in many deregulated industries. Pure innovations may result from this imitative technological race.

\section{Suggestions for Future Research}

This study has established a theoretical link between innovation and the sunk character of a firm's cost structure and examined it empirically. Although the results are quite interesting and revealing, it is important, however, to note that they have been 
obtained from data of a limited sample size. Longer time series and cross-section data are necessary for improving the inferential ability of the model. Furthermore, effort has to be made in order to develop appropriate indices for sunk costs and the appropriability effects. The findings of this paper would be further enriched by future empirical analysis based on international data from intensive $R \& D$ industries. The author is currently involved in a project aiming at correcting the weaknesses mentioned above.

I would like to thank professors Petr Hanel, Pierre Mohnen, Richard Nelson, Sylvia Ostry and the INSEE seminar participants for making valuable comments and suggestions. A preliminary version of this paper was presented at the seminar on "Technological Appropriation" organized by INSEE, Paris, France, June 9-10, 1992. Financial support was provided by SSHRCC grant \#80991-0003.

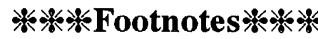

1. Spillovers are a kind of externalities resulting from a firm's or an industry's R\&D activities. Normally, a firm realizing $R \& D$ is unable to capture the full benefits resulting from its innovations. This may dump its R\&D effort. On the other hand, given that the individual $R \& D$ activities contribute to the pool of knowledge, it may induce other firms to realize more $R \& D$.

2. This may be attributed to the fact that a large body of work has been accomplished in static terms. Static analysis cannot account for the changing needs of firms in industries that evolve over time. It has been recently recognized that market structure may not be given exogenously but it may be determined by technical change. As technology diffuses, markets evolve and industries, formerly discrete, may converge. In such circumstances, a continuous interaction exists that comes from innovation to market structure and from market structure to innovation. This basic interaction characterizes most of the markets especially those of computers and telecommunications.

3. This definition abstracts from the more elegant, albeit less operational one, according to which innovation is distinguished into technical change (the incremental changes in process and/or products) and technological innovation (the use of major new ideas and techniques).

4. The subject of barriers to entry in the presence of sunk costs was treated originally by Baumol et al (1982). Although they do not make the distinction between innovative and imitative entry, their theory is applied to imitative entry only.

5. An interesting example of competition by innovation is, no doubt, the home computer industry. Rapid technological change has had as a result the appearance of smaller yet powerful computers at lower prices. This product innovation has brought about important process innovations used by many industrial sectors such as telecommunications, aerospace and automotive industries.

6. Given the same product characteristics, incumbents, however, would find it more profitable to get involved in product innovations rather than pure cost-reducing process innovations of a homogeneous product. This assertion finds partial support from casual observation of the computers and electronics industries. To the extent new firms enter the computer industry with cost-reducing technologies, IBM responds by differentiating its product and by developing new ones rather than by further reducing costs of the homogeneous product.

7. Incumbents may be engaged in other entry deterring activites some of which are less socially beneficial. These may be explicit agreements such as joint ventures and/or strategic alliances. These entry deterring activities may not be considered a priori as less socially beneficial.

8. Capital may be physical and R\&D. The distinction will be hard to make in practice. Since R\&D capital is much more important than the physical capital and given that the sunkness of costs is mostly related to the R\&D capital we blur the two terms in the generic term "capital" which includes both forms of capital.

9. The personal computers and mainframe industries may be used as an illustration. The profit margins in the mainframe industry are very high, yet this segment of the market is a declining one, therefore no entry is observed. By contrast, the personal computer industry is a growing one but the profit margins are meagre, yet new entrants are flooding this market segment.

10. When externalities of this kind exist, the natural reaction of firms would be to internalize them. Depending on the intensity of externalities some firms would opt for a full internalization by outright acquisition of the externalities-creating firms. However, strategic alliances and/or looser other forms of cooperation would be used when spillover effects are weak.

11. Bernstein (1988) applies a $10 \%$ uniform rate of depreciation to R\&D investments irrespective of the industrial activity concerned.

12. These are standard assumptions in pooled time-series cross-sectional regression analysis.

\section{Appendix}

Construction of variables and regression results

The results of the regression model, the associated t-statistics and the key overall model statistics are set out in Table 2. 


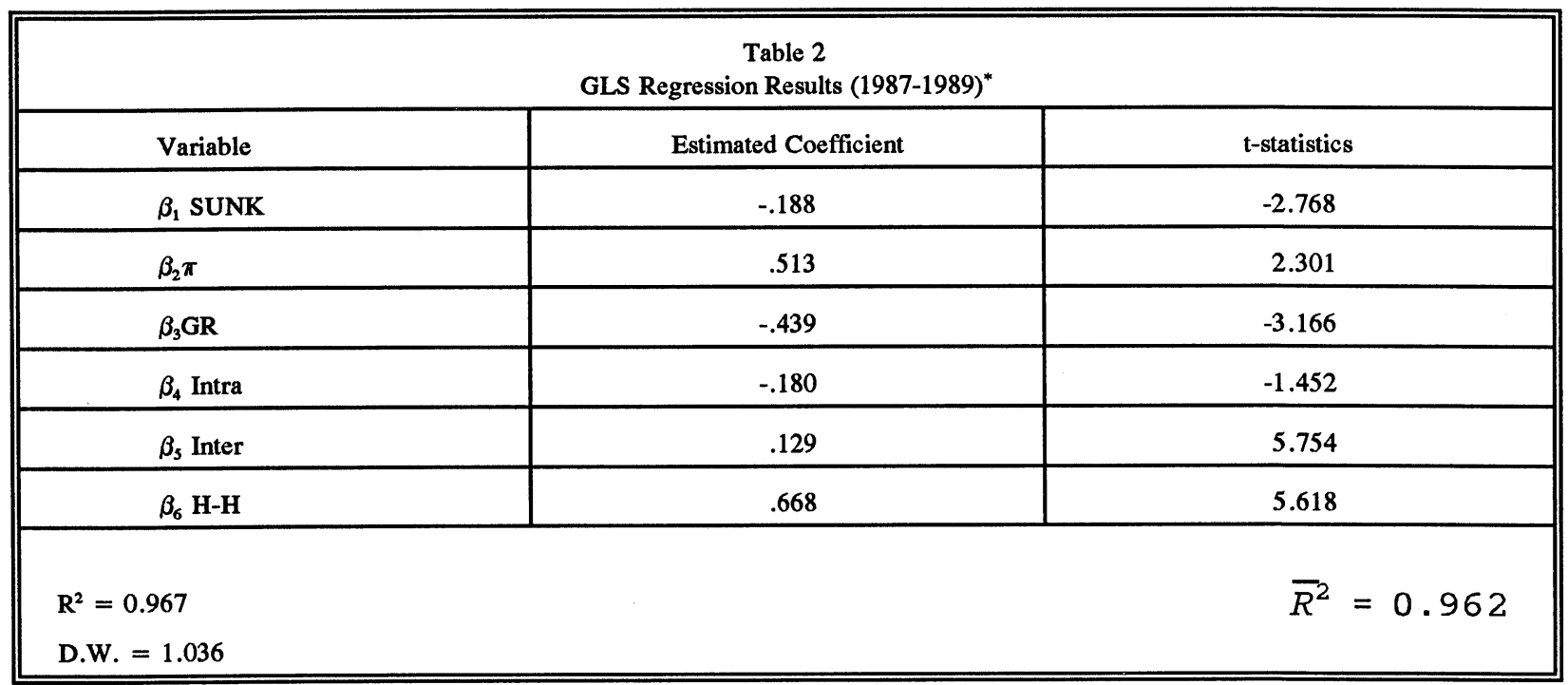

* We have applied a uniform $10 \%$ depreciation rate to sunk variable.

The $R^{2}$ is 0.967 , indicating a good fit for cross-sectional data. To fine tune the model we estimated alternative specifications that differed from the base model (presented here) only in terms of restrictiveness. The results of these sensitivities suggest that the base model cannot be rejected in favor of any model which incorporates fewer restrictions. Considering that R\&D capital is composed by the aggregation of laboratories and scientific equipment, scientists and engineers and related materials, the SUNK variable is measured by

SUNK $=$ KR (1-nANDEP)

where

$\mathrm{KR}=$ the sum of the components of $\mathrm{R} \& \mathrm{D}$ capital $\mathrm{n}=$ number of years that the entrant will be in the market

$\mathrm{ANDEP}=$ annual depreciation rate (assumed here to be $10 \%$ ).

It is not possible to get a market rental cost of $R \& D$ capital given the absence of a secondary market for "used knowledge. Bernstein (1988) mentions the work of Mansfield and others in Williams (1973) and that of Pakes and Schankerman (1984) to justify the application of $10 \%$ R\&D capital depreciation rate to his study, since it seems that the R\&D capital (knowledge) depreciates faster than the physical capital with little left past ten years.

However, following Goto and Suzuki (1989) we applied as well a different rate of depreciation depending on the type of each firm's activity. That is, the R\&D investments of firms belonging to industries with high rates of technical change are depreciated faster than the R\&D investments in industries which experience slower rates of technical change. Thus, we apply a depreciation rate of $24.6 \%$ to the firms belonging to the electronic parts and components and other electronic equipment industries, manufacture, engineering and scientific and computer services. A depreciation rate of $14.5 \%$ is applied to the firms belonging to the telecommunications and aircraft industries, while a rate of $7.2 \%$ is applied to firms in the manufacturing industry. Lastly, a rate of $7.5 \%$ is applied to drugs and medicine industry.

Given the difficulty in obtaining data on appropriability we use a more mundane index of intra-industry and inter-industry spillover effects. Bernstein (1988) denotes the two spillover variables as $\mathrm{S}=\left(\mathrm{S}_{1}, \mathrm{~S}_{2}\right)$ where $\mathrm{S}_{1}$ represents the intra-industry spillovers and $S_{2}$ the interindustry spillovers. $S_{1}$ is measured as the sum of the R\&D capital stocks of all firms, but the representative firm in the same industry $\left(S_{1}=\Sigma_{i} K_{r}^{i}\right) . \quad S_{2}$ is measured as the sum of the $R \& D$ capital stocks of all industries, but the representative one $\left(S_{2}=\Sigma_{j} \Sigma_{i} K_{r}^{j i}\right)$, where $i$ stands for the firms and $j$ for the industries.

\section{***\%References $* \% *$}

1. Arrow, K.J., "Economic Welfare and the Allocation of Resources to Invention", in Nelson, R.R., (ed), 
The Rate and Direction of Inventive Activity, Princenton University Press, 1962.

2. Abernathy, W.J., and Utterback, J., "Pattents of Industrial Innovation", Technology Review, 40-47, 1978.

3. Abernathy, W.J., and Clark, K.B., "Innovation: Mapping the Winds of Creative Destruction", Research Policy, 14, 1985.

4. Baumol, W. J., Panzar, J., and Willig, R., Contestable Markets and the Theory of Industry Structure, Harcourt Brace Jovanovitch, Inc., 1982 and 1987.

5. Beath, J., Katsoulacos, Y. and D. Ulph., "Strategic R\&D Policy" The Economic Journal (Conference), 1989.

6. Bernstein, J.I, "Cost of Production, Intra- and Interindustry R\&D Spillovers: Canadian Evidence", Canadian Journal of Economics, 88, 324-47, 1988.

7. Bernstein, J.I, and Nadiri, I.M., "Interindustry R\&D Spillovers, Rate of Return, and Production in High-Tech Industries", American Economic Review 78, 429-34, 1988.

8. Burns, R.J., and Stalker, G.M., The Management of Innovation, Tavistock, London, 1986.

9. Denison, E.F., "Sources of Postwar Growth in Nine Western Countries", American Economic Review, May, 1967.

10. Dewar, R.D., and Dutton, J.E., "The Adoption of Radical and Incremental Innovations: An Empirical Analysis", Management Science, 32, 1422-33, 1986.

11. Dixit, A., "The Role of Investment in Entry-Deterrence", Economic Journal, 90, 95-106, 1980.

12. Eaton, C. B. and Lipsey, R.G., "Exit Barriers are Entry Barriers: The Durability of Capital as a Barrier to Entry", Bell Journal of Economics, Autumn, 1980.

13. Friedman, J. W.,"On Entry Preventing Behaviour and Limit Price Models of Entry", In Applied Game Theory, by Brans, S.J., A. Schotter, and G. Schwodiauer, pp. 236-53, Wurzburg: Physica-Verlag, 1979.

14. Gentzoglanis, A., "Entry, Sunk Costs and Innovation", Discussion Paper, no. 90-09, University of Sherbrooke, 1990.

15. Gilbert, R. J. and Newbery, D.M.G., "Preemptive Patenting and the Persistence of Monopoly", American Economic Review, 1982.

16. Goto Akira and Suzuki, K., "R\&D Capital, Rate of Return on R\&D Investment and Spillover of R\&D in Japanese Manufacturing Industries", The Review of Economics and Statistics, Vol. LXXI, no 4, pp. 555-64, November, 1989.

17. Grossman, G. and Shapiro, C. ,"Dynamic R\&D Competition", Economic Journal, 1987.

18. Harris, C. J. and Vickers, J., "Racing With Uncertainty", Review of Economic Studies, 1987.

19. von Hippel, E., "Appropriability of Innovation
Benefits as a Predictor of the Innovation", Research Policy, 11, 95-115, (1982).

20. Jewkes, J., Sauyers, D., and Stillerman, R., The Sources of Invention, MacMillan, London, 1958.

21. Kamien, M. I. and Schwartz, N. L., Market Structure and Innovation, Cambridge, Cambridge University Press, 1982.

22. Kessides, I.N., "Entry and Market Contestability: The Evidence from the United States", in Entry and Market Contestability: An International Comparison, Geroski, P.A., and Schwalbach, J., eds., Basil Blackwell, 1991.

23. Mansfield, E., Husic, F., Rapport, J., Romeo, A., Villani, E., and Wagner, S., The Production and Application of New Industrial Technology, New York, W.W. Norton, 1977.

24. Mata, J., "Sunk Costs and Entry by Small and Large Plants", in Entry and Market Contestability: An International Comparison, Geroski, P.A., \& Schwalbach, J., eds., Basil Blackwell, 1991.

25. Pakes, A., and Schankerman, M., "The Rate of Obsolenscence of Patents, Research Gestation Lags and the Private Rate of Return to Research Resources", in Patents and Productivity, Griliches, Z., ed. Chicago, NBER, 1984.

26. Reinganum, J.F., "Innovation and Industry Evolution", Quarterly Journal of Economics, 1985.

27. Reinganum, J.F., "The Timing of Innovation: Research and Development, and Diffusion" in Schmalensee, R., \& R.D. Willig (ed) Handbook of I.O., Elsevier Science Publishers, 1989.

28. Roberts, E.B., "Getting New Ventures off the Ground", Management Science, June 1980.

29. Scherer, F.M., \& D. Ross, Industrial Market Structure and Economic Performance, Houghton Mifflin Company, Boston, 1990.

30. Schumpeter, J.A., Capitalism, Socialism and Democracy, New York: Harper and Row, 1950.

31. Solow, R.M.,"Technical Change and the Aggregate Production Function", Review of Economics and Statistics, pp. 312-320, 1957.

32. Spence, M.A., "Entry, Capacity, Investment and Oligopolistic Pricing", Bell Journal of Economics, 8, 534-44, 1977.

33. Stiglitz, J.E., "Technological Change, Sunk Costs, and Competition", Brookings Papers on Economic Activity, No 3, 1987.

34. Stiglitz, J.E., "Potential Competition May Reduce Welfare" American Economic Association, Papers and Proceedings, May, 1981.

35. Tang, M., and Zannetos, Z.,S., "Competition Under Continous Technological Change", Managerial and Decision Economics, 13, 135-148, 1992.

36. Teece, D.J., "Profiting form Technological Innovation: Implications for Integration, collaboration, Licencing and Public Policy", Research Policy, pp. 286-305, 1986.

37. Tirole, J., The Theory of Industrial Organization, The 
MIT Press, 1988.

38. Utterback, J.M., "The Dynamics of Product and Process Innovation in Industry" in Christ. T. Hill and J. M. Utterback, eds. Technological Innovation for a Dynamic Economy, New York: Pergamon Press, 1979.

39. Vickers, J., The Evolution of Market Structure When There is A Sequence of Innovations, The Journal of Industrial Economics, September, 1989.

40. Yip, G., Barriers to Entry: A Corporate Strategy Perspective, D.C. Heath, Lexington, MA, 1982.

41. Williams, B.R., Science and Technology in Economic Growth, MacMillan, London, 1973.

42. Winter, S.G., "Schumpeterian Competition in Alternative Technological Regimes", Journal of Economic Behavior and Organization, 5, 287-320, 1984. 